\title{
Determination of Nickel Concentration in the Breast Milk of Lactating Mothers Living In Hilla City, Babylon, Iraq
}

\author{
Ishtar Munim Nassir $^{\mathrm{a}} \quad$ Abaas Noor Al-Sharify $^{\mathrm{b}}$ Hasan Alwan Baiee $^{\mathrm{c}}$ \\ ${ }^{a}$ Babylon Health Directorate \\ ${ }^{b}$ College of Science, University of Babylon \\ ${ }^{c}$ College of Medicine Babylon University \\ Ishtar_65r@yahoo.com
}

Submission date:- 27/1/2018 Acceptance date:- 7/3/2018 Publication date:- 2/9/2018

Keywords: Nickel, breast milk, lactating women, Hilla city, Babylon, Iraq

\begin{abstract}
Background

Human milk is the only source of food for infants during the first four to five months of their life. Some chemicals compood can be transferred from the body stores and from blood into the breast milk of a lactating mother.
\end{abstract}

\section{Objectives}

To determining and measurements of Nickel leval the human milk and to identify the associations of certain potential variables with the concentrations of these heavy metals.

\section{Subjects and Methods}

This is a cross sectional study carried included a milk test by a randomly selected (68) women apparently healthy lactating women, who attended Babylon Maternity \& children hospital in Al - Hilla city during the period mid of February through the end of April, 2012. Breast milk was collected and analyzed to detect and measure Nickel using atomic absorption. A questionnaire paper was preparedto recored the demographic variables. Weights and heights were measured to calculate the Body Mass Index.

\section{Results}

This study revealed that the mean concentrations of Nickel in the human milk was $(23.83 \pm 15.57 \mathrm{ppb})$ which was remarkably high as compared with the concentrations reported by other studies done in other countries. The study shows that there was a statistically significant association $(\mathrm{p}<0.0 \mathrm{~s})$ between the high concentrations of Nickel and the followings associates; living in urban regions, living near highways, living near industrial regions and drinking river or tap water, being younger (<3oyears of age) or heaver increase weight and being cigarettes smokers. The prevalence rates of lactating mothers with abnormal concentrations of was $99 \%$ and $93 \%$ respectively indicating the serious environmental pollution in Hilla city.

\section{Conclusion}

Breast milk of lactating mothers in Hilla city is abnormally contaminated with; Nickel this public health problem need to be addressed. 


\section{1- Introduction}

Environmental factors increasing gain importance in public health. Children are affected more than adults from environmental deterioration and harmful effects. Children's exposure to environmental hazards may cause permanent damage and will continue during adulthood, Over the past century, there has been an increasing awareness throughout the world of the health and developmental risks associated with environmental exposure to toxic metals, such as, lead $(\mathrm{Pb})$, mercury $(\mathrm{Hg})$, cadmium $(\mathrm{Cd})$, Iron $(\mathrm{Fe})$, and Nickel $(\mathrm{Ni})$. While exposure to toxic levels of any of these environmental contaminants may result in impaired health in adults, the toxicological effects of these metals are often more devastating in the developing central nervous system and general physiological systems of children [1]. Although $\mathrm{Pb}$ is perhaps the most publicized and well known of the pediatric metal intoxicants, environmental pollution in different country or regions, even in rural areas may adversely affect to human life .Air currents, mixing of water sources with metals, the use of leaded gasoline, lead pipes in drinking water transport, and traditional methods of food storage containers in rural sector can make the world more risky in terms of environmental pollution [2].

On the other hand, human milk is also a unique biological matrix for monitoring certain environmental contaminants because it can provide exposure information about both the mother and the breastfed infant through a non-invasive method of collection. Human milk is considered to be one of the most important biota to be monitored for the presence of Persistent Organic Pollutants (POPs). Better understanding of our exposure to harmful environmental chemicals will help us better to manage such chemicals by eliminating or reducing pollutions emissions of such toxic materials or by limiting their presence in the air, food, and water supply[3].

\section{2- Subjects and methods}

breast milk samples was collected and analyzed from (68) apparently healthy mothers, started from the mid of February through the end of April, 2012.

Breast milk samples was collected on1-6 weeks postpartum from the respondent lactating mothers who volunteered to participate in this study, their informed consents was obtained after explaining to the objectives and the methodology of this work. Before the self manually expressing milk using a conventional breast pump; the breast was washed by deionized water (distilled water) to avoid contamination with environmental heavy metals, the first few drops was discarded, and only the midstream flow was collected.

Ten (10) milliliter of milk was collected in sterile polypropylene tubes, samples were immediately transferred to a special cooling box with thermometer (temperature of the ice containing box -18 to $-21 \mathrm{C}^{\circ}$ ).

The samples were transferred for analysis to the chemical laboratory of the chemical department in the college of science - Babylon University and stored in the deep freeze at $-30 \mathrm{C}^{\circ}$, . The concentrations of cadmium and lead was determined by the graphite furnace atomic absorption spectrometry calibration curve was performed by prepared known concentration of $\mathrm{Ni}$ with absorbance (nm) of atomic absorption (fig.1).

A questionnaire was used to collect information about the following variables:

Age, occupation, Place of residency near industrial regions (less than 200 meter radius) to the following industrial areas; (districts of car repairing, battery re-charging and repairing workshops, radiator repairing shops, automobile exhaust tubes repairing districts, Arc welding workshops; as well as living near industrial factories).

1- Mothers living within or less than 200 meter radius from highways (street) was considered as dwellers near the street.

2- The questions included information about the history of types of drinking water (Tap, Bottled, or drinking from rivers).

3- Questions about cigarette smoking habits was included in the structured questionnaire, the smokers in this study are women who were currently smoking at the time of collecting data or they had quitted smoking within the last six months. 4 women mentioned that their husbands are smokers (passive smokers) are also included in the smoking group, none of the smokers mentioned that they smoke water pipe (Shisha).

4- Height and weight of mothers was measured and the body Mass Index (BMI) was calculated according to the following equation : Weight in Kilograms/ (Height in meter) ${ }^{2}$ [4]. 


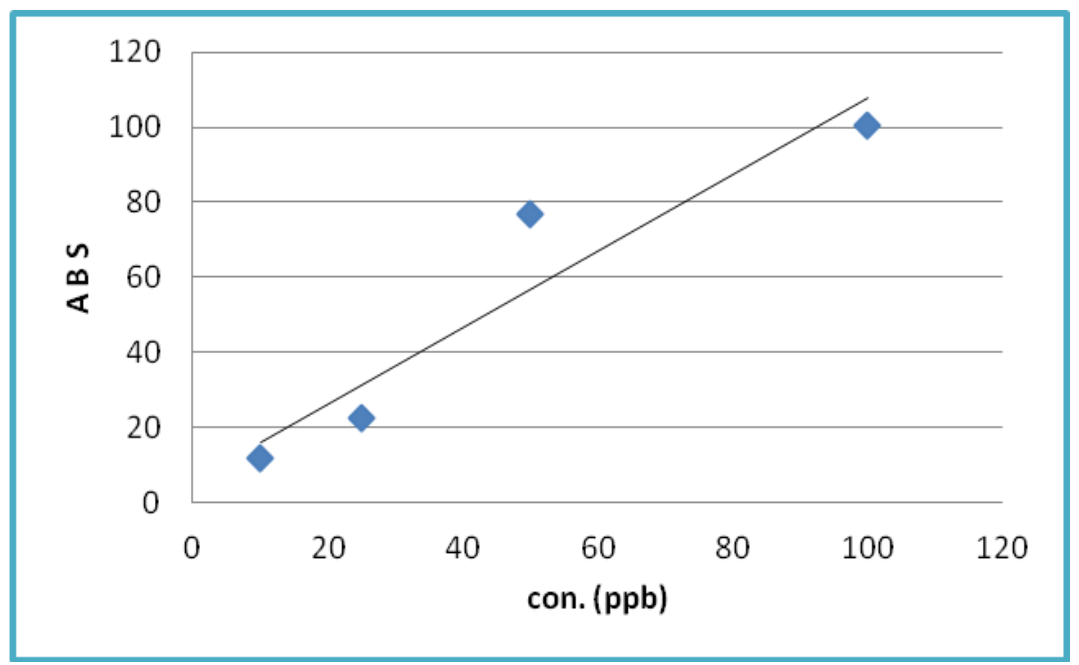

Figure (1) calibration curve of $\mathrm{Ni}$ at $232 \mathrm{~nm}$ in atomic absorption

\section{3- Statistical Analysis}

Using SPSS version / 17 statistical software, Both statistical analysis and tabulation was carried out. Data was summarized as means (X) and standard deviation (SD). Differences were analyzed using Student'st test and Analysis of Variance (ANOVA-one way) for comparison between groups. Differences were considered as statistically significant at values $\mathrm{P}<0.05$.

\section{4- Results}

Table (1) shows that the concentration of Nickel was significantly higher $(\mathrm{p}<0.05)$ in rural region $(\mathrm{p} \leq 0.05)$. Table (2) reveals that the concentrations of this heavy metal increased in lactating mother's milk who are living near highways as compared to those living far away from these streets, this difference is statistically significant $(\mathrm{p} \leq 0.05)$.

The association of Body Mass Index with heavy metal concentrations in the milk of lactating mothers was evident in the table (3), obesity was associated significantly with the increment in Ni concentration $(\mathrm{p} \leq 0.05)$.

Living near industrial area has been associated with the contamination of breast milk with heavy metal, this association was presented in table (4), living near industrial areas was associated significantly $(p \leq 0.05)$ with high concentrations of Ni. Table (5) shows that tap water and river water consumption was significantly associated with high levels of this heavy metal. Table (6) reveals the association of smoking with heavy metal concentration, the results show that smoking mothers have ahigh concentration of $(\mathrm{Ni})$ in their milk at significant level $(\mathrm{p} \leq 0.05)$. Table (7) shows that the concentrations of $\mathrm{Ni}$ in the milk was at high levels in lactating mothers. Table (8) shows that the concentrations of heavy metals in the milk of the current study were remarkably higher as compared to the concentrations reported by other researchers in other countries. Table (9) shows the prevalence rates of mothers with abnormal concentrations of $(\mathrm{Ni})$ in their milk.

Table (1) Distribution of means and standard deviations of age body mass index and number of cigarettes smoked per day of lactating mothers .

Table (1) Concentration of heavy metal Ni $(\mu \mathrm{g} / \mathrm{L})$ of lactating mother's milk according to place of residency

\begin{tabular}{|l|l|l|l|}
\hline Place of residency & No & $\%$ & $\mathrm{Ni}$ \\
\hline Urban & 32 & 47 & $24.95 \pm 19.55$ \\
\hline Rural area & 36 & 53 & $30.81 \pm 16.59$ \\
\hline t-calculate & & & $* 2.40$ \\
\hline
\end{tabular}

$* \mathrm{P}<0.05$ 
Table (2) Concentration of heavy metal $\mathrm{Ni}(\mu \mathrm{g} / \mathrm{L})$ in lactating mother's milk by place of resident near streets.

\begin{tabular}{|c|c|c|c|}
\hline Place of street & No & $\%$ & Ni \\
\hline Near street & 32 & 47 & $31.59 \pm 17.41$ \\
\hline For away street & 36 & 53 & $25.3 \pm 18.89$ \\
\hline t-calculate & & & $* 2.5$ \\
\hline
\end{tabular}

Table (3) Concentration of heavy metal Ni $(\mu \mathrm{g} / \mathrm{L})$ in lactating mother's milk according to their body mass index

\begin{tabular}{|l|l|l|l|}
\hline BMI & No & $\%$ & $\mathrm{Ni}$ \\
\hline Normal weight & 16 & 23.5 & $20.29 \pm 3.98$ \\
\hline Over weight & 33 & 48.5 & $24.87 \pm 2.72$ \\
\hline Obesity & 19 & 28 & $29.56 \pm 5.17$ \\
\hline f-calculated & & & $1.58^{*}$ \\
\hline
\end{tabular}

$* \mathrm{p}<0.05$

Table (4) Concentrations of heavy metal Ni $(\mu \mathrm{g} / \mathrm{L})$ in lactating mother's milk according to living near industrial areas

\begin{tabular}{|l|l|l|l|}
\hline Area & No. & $\%$ & $\mathrm{Ni}$ \\
\hline Industrial area & 22 & 42.4 & $30.99 \pm 12.98$ \\
\hline Normal area & 46 & 67.5 & $24.31 \pm 13.40$ \\
\hline t-calculated & & & $* 2.09$ \\
\hline
\end{tabular}

$* \mathrm{p}<0.05$

Table (5) Concentration of heavy metal $\mathrm{Ni}(\mu \mathrm{g} / \mathrm{L})$ in lactating mother'smilk by types of drinking water

\begin{tabular}{|l|l|l|l|}
\hline Drinking water & No & $\%$ & $\mathrm{Ni}$ \\
\hline Tap water & 43 & 63.3 & $26.15 \pm 2.31 \mathrm{a}$ \\
\hline bottle water & 18 & 26.5 & $17.4 \pm 2.43 \mathrm{~b}$ \\
\hline River water & 7 & 10.2 & $22.12 \pm 5.42 \mathrm{c}$ \\
\hline f- calculated & & & 6.27 \\
\hline
\end{tabular}

Mean \pm SE different letters refer to significant between groups at ( $\mathrm{p} \leq 0.05)$ (ANOVA- one way) 
Table (6) Heavy metals concentrations (Ni) in human milk according to smoking habit

\begin{tabular}{|l|l|l|l|}
\hline Smoking & No & $\%$ & $\mathrm{Ni}$ \\
\hline Smoker mothers & 8 & 11.8 & $47.5 \pm 20.05$ \\
\hline Nonsmoker mothers & 60 & 88.2 & $20.68 \pm 11.89$ \\
\hline t-calculated & & & $3.23^{*}$ \\
\hline
\end{tabular}

$* \mathrm{p}<0.05$

Table (7) Concentration of heavy metal Ni $(\mu \mathrm{g} / \mathrm{L})$ in lactating mother's milk according to age

\begin{tabular}{|l|l|l|l|}
\hline \multicolumn{1}{|c|}{ Age (year) } & No. & $\%$ & $\mathrm{Ni}$ \\
\hline $16-20$ & 12 & 17.6 & $30.27 \pm 2.99 \mathrm{a}$ \\
\hline $21-25$ & 21 & 30.9 & $20.82 \pm 4.67 \mathrm{~b}$ \\
\hline $26-30$ & 20 & 29.4 & $29.14 \pm 1.89 \mathrm{a}$ \\
\hline $31-35$ & 7 & 10.3 & $50.97 \pm 4.49 \mathrm{c}$ \\
\hline $36-40$ & 8 & 11.8 & $11.92 \pm 5.11 \mathrm{~d}$ \\
\hline f-calculated & & & 7.35 \\
\hline
\end{tabular}

Mean $\pm S E$, different letters refer to significant at $(\mathrm{p} \leq 0.05)$ between groups (ANOVA-one way)

Table (8) Comparison between Ni concentration of the current study and studies in other countries

\begin{tabular}{|l|l|}
\hline Country & $\mathrm{Cd}(\mu \mathrm{g} / \mathrm{L})$ \\
\hline Turkey & 3 \\
\hline USA & 15 \\
\hline Present study (Iraq) & $23.83 \pm 15.57$ \\
\hline
\end{tabular}

Table (9) Prevalence rate of women with abnormal concentrations of heavy metal Ni in their milk

\begin{tabular}{|l|l|l|l|}
\hline Heavy metal & Total & abnormal & $(\%)$ \\
\hline $\mathrm{Ni}$ & 68 & 45 & 66 \\
\hline
\end{tabular}




\section{Discussion}

In this study the concentrations of $\mathrm{Ni}$ in the breast milk of Iraqi lactating mothers are high. This finding reflected the severity of local environmental pollution with the studied heavy metals $(\mathrm{Ni})$.

In comparison with other studies in the neighboring countries and other countries, our results show a significant increase in the concentrations of the studied heavy metal which bring our attention to a serious hazardous environmental problem which may affect on the health of Iraqi mothers and their children.

Our study revealed differences of heavy metals concentrations in lactating mother's milk in urban and rural area , Ni and Fe was higher in rural. Cinar et al (2011) measured some heavy metals in Turkish lactating mother's milk they found similar results [5].

The concentration of Nickel in human milk in rural area was higher than urban area, this may be because this metal can exist in soils in several forms: inorganic crystalline minerals or precipitates, complexed or adsorbed on organic cation surfaces or on inorganic cation exchange surfaces, water-soluble, free-ion or chelated metal complexes in soil solution [6], [7], and [8]. Nickel may present a major problem in land near towns or even in agricultural land receiving wastes such as sewage sludge. Its content in soil varies in a wide range from 3 to 1000 $\mathrm{mg} / \mathrm{kg}[6]$, [9], and [10].

Milk of lactating mothers living near highway streets had high concentration of heavy metals as compared to mothers living far from the streets, this finding is in consistent with the finding of other studies [11], [12] this can be explained. Street dusts and top roadside soils in urban area are indicators of heavy metal contamination from atmospheric deposition. The source of $\mathrm{Ni}$ and $\mathrm{Cr}$ in street dust is believed to be due to corrosion of cars [13], [14]; and chrome plating of some motor vehicle parts [15] respectively.

Streets are densely regions by different vehicles and cars that cause air pollution, Components and quantity of street dust are environmental pollution indicators especially in big cities. Street dust is generally composed of car exhaust gas originated particles and wind-transported particles. Heavy metals, which are found in street dust, such as $\mathrm{Pb}, \mathrm{Cd}$ and $\mathrm{Ni}$ are significant for environmental pollution. According to the kind of vehicle in traffic, quantity and type of heavy metals vary in street dust that effected on minerals in human milk; blood and tissue such as accumulate $\mathrm{Pb}$ in bones, blood, urine and milk especially during pregnancy and postpartum [16].

In this study living of lactating mothers near industrial area was associated significantly with high concentration of $\mathrm{Ni}$ in their milk. In turkey other researchers found increased in $\mathrm{Ni}$ and $\mathrm{Cd}$ in city center to 3 , and $31 \mathrm{ppb}$ respectively, $\mathrm{Pb}$ and $\mathrm{Fe}$ also increased in city center and in industrial areas [17]. Singh et al (2010) clarified that heavy metals concentrations increased in human milk via dietary intake of foodstuff from the weste water [18], so the vegetables growing in the vicinity of an industrial area causes increased in $\mathrm{Cd}, \mathrm{Cu}, \mathrm{Zn}, \mathrm{Cr}$ and $\mathrm{pb}$ concentration in different part of these vegetable that reflect high level of these metals in human milk [19].

$\mathrm{Ni}$ is increasing related to weight or BMI this is may be due to excessive meal intake that containing $\mathrm{Ni}$ results from food processing methods apparently add to the nickel levels already present in foodstuffs via: 1. Leaching from nickel-containing alloys in food processing equipments made from stainless steel; 2 . the milling of flour; 3.catalytic hydrogenation of fats and oils by use of nickel catalysts [20]. Rich food sources of nickel include oatmeal, dried beans and peas, nuts, dark chocolate and soya products, and consumption of these products in larger amounts may increase the nickel intake to $900 \mu \mathrm{g} /$ person/day or more [21].

Nickel levels in some vegetables and fruits, in fruit and vegetable juices, in wine and cocktails were within the limits of standards [22],[23] similarly, nickel contents in instant coffee brands, in some natural ground coffees, coffee beans and coffee infusions did not exceed the allowable concentration values stated in relevant Polish regulations. However, a significant relationship was observed between the levels of the nickel in coffee infusions and coffee beans [24],[25]. The concentrations of nickel in bee honey, confectionery products, dry herbs, tea leaves and granulated tea were also below the corresponding allowable values [26], [27].

In this study the concentrations of (Ni) in the human milk of lactating mothers drinking tap and river water were high significantly increased, this may result from contamination of river water by the chemical west from industrial plant or from using herbicide, insecticide in high rate, study of Iraqi rivers especially in Euphrates show increased in heavy metals like $\mathrm{Pb}$, Ni concentrations [28]. According to WHO study drinking water generally contains $\mathrm{Ni}$ at concentration less than $10 \mathrm{ppb}$ consumed daily of $1.5 \mathrm{~L}$ of water and a level of 5-10 microgram $\mathrm{L}$, the mean daily intake of $\mathrm{Ni}$ from water for adults would be between 7.5 and 15 microgram [29].

In the present study 8 of lactating mothers were smokers, this bad habit cause increasied in heavy metal level in their milk. Ni levels raised in smoking lactating mother's milk because the tobacco is considered as $\mathrm{Ni}$ source, it has been estimated that each cigarette contains $\mathrm{Ni}$ in a quantity of 1.1 to $3.1 \mu \mathrm{g}$ and about $10-20 \%$ of $\mathrm{Ni}$ inhaled is present in the gaseous phase, according to some researchers $\mathrm{Ni}$ in tobacco smoke may be present in the form of nickel carbonyl, a form which is extremely hazardous to human health[29]. Stjanovic and Nikic (2005) detected Ni concentration in smoking and non-smoking mothers blood, placenta, serum, urine and milk they found high Ni concentration in smoking mothers than non-smoking mothers [30].

\section{Aknowledgement}

We are highly indebted to the study participants and to the staff of investigators, special thanks to prof. Dr. Ali Alsaadi for his active contribution .Thanks is also due to Dr Noor Hasan Baiee. 


\section{CONFLICT OF INTERESTS}

\section{There are no conflicts of interest.}

\section{References}

[1] J. P.H. landrigan, B Sonawane, D.Mattison, and M. McCally. "Chemical contaminants in breast milk and their impact on children health; an overview". Enviro.Health, prespect.110,313-315. 2002.

[2] K. Nickerson. "Environmental contaminants in breast milk". J. Midwifery women health, 51,26-34. 2006.

[3] Environmental Health Series No.34.. Levels of PCBs, PCDDs, and PCDFs in breast milk, WHO Regional Office for Europe, Copenhagen, Denmark. 1989.

[4] J. Gadzik. How much should weight? Quantities equation, upper weight limits and body mass index prime. connect medicine 70,81-88. 2006

[5] N.Cinar, S.Ozdemir, O. Yucel and F. Ucar. In which regions is breast-feeding safer from the impact of toxic elements from the environment? Bosn J. basic med.Sci. 11, 234-239. 2011.

[6] T.W. Clarkson,. Biological monitoring of toxic metals, Plenum press: New York, 265-282. 1988.

[7] J.J Scott-Fordsmand. Toxicity of nickel to soil organisms in Denmark. Rev. Environ. Contam.Toxicol.148, 1. 1997.

[8] B.G. Bennett. Exposure of man to environmental nickel an exposure commitment assessment. sci. Total. Environ .22, 203. 1982.

[9] V.Bencko. "Nickel: A review of its occupational and environmental toxicology". J. Hyg. Epidem. Micro. Immun. $27,237.1983$.

[10] W. Wilcke, and M. Kaupenjohann.”Heavy metal distribution between soil aggregate core and surface fractions along gradients of deposition from the atmosphere". Geoderma 83, 55-66. 1998.

[11] M.Leotsinidis, A.Alexopoulos, and E.Kostopoulou-Farri. "Toxic and essential trace elements in human milk from Greek lactating women: association with dietary habits and other factors". Chemosphere, 61:238-47. 2005.

[12] M.S. khter, and I.M. Madany. "Heavy metals in street dust and house dust in Bahrain", Water Air Soil Pollut., 66: 111-119. 1993.

[13] C.H. Tamrakar and P.R. Shakya. "Assessment of Heavy Metals in Street Dust in Kathmandu Metropolitan City and their Possible Impacts on the Environment". Pak. J. Anal. Environ. Chem 12,32-41. 2011.

[14] T.Chirenje, L.Q. Ma and L. Lu. Retention of $\mathrm{Cd}, \mathrm{Cu}, \mathrm{Pb}$ and $\mathrm{Zn}$ by wood ash, lime and fume dust. Water Air Soil Pollut. 171:301-314. 2006.

[15] B.Gulson, B. Mizon , M. Korsch , J. Palmer and J. Donnelly. "Mobilization of lead from human bone tissue during pregnancy and lactation”. Science of The Total Environment,303, 79-104. 2002.

[16] M.R. Sim and J.J. McNeil. "Monitoring chemical exposure using breast milk: a methodological review". Am J Epidemiol 136,1-11. 1992.

[17] N.Cinar, S.Ozdemir, O.Yucel and F. "Ucar. In which regions is breast -feeding safer from the impact of toxic elements from the environment?”. Bosn J. basic med.Sci. 11, 234-239. 2011.

[18] A. Singh, R. K.Sharma, M. Agrawal and F. M. Marshall. "Health risk assessment of heavy metals via dietary intake of food stuffs from the west water irrigated site of a dry tropical area of India". Food and chemical toxicology, 48,611-619. 2010.

[19] M.Farooq, F. Anwar and U. Rashid. "Appraisal of heavy metal contents in different vegetables grown in the vicinity of an industrial area”. Pak. J. Bot 40,2099-2106. 2008.

[20] R. Vonburg. "Toxicology update". J. Appl. Toxicol. 17, 425. 1997.

[21] M.M.Brzoska, W. Kasjanowicz, M. Galazyn-sidorczuk, M. Jurczuk, J. Rogalska and J.Moni-uszko-Jakoniuk. "Estimation of heavy metals content in plants and soils from the Podlasie Province". Polish J. Environ. Studies,8,125. 1999.

[22] A. Jagiello, M. Bozym and W. Waclawek ."Location of contaminants in anatomic parts of vegetables grown in allotment gardens of Nysa. part II: Heavy metals and 1-ascorbic acid. Bromat”. Chem. Toksykol. 37,335. 2004.

[23] R. BullńskI, Wyszogrodzka-Komal. and Z.Marzec. "Determination of metal levels in cocktails, grape and fruit wine. Bromat".Chem.Toksykol. 28, 253. 1995.

[24] R. Bulinski and J. Bloniarz."Studies on some trace element content (lead, chromium, zinc, manganese, copper ,nickel and iron) of instant coffee". Bromat. Chem. Toksykol .219,3.1998. 
[25] J. Błoniarz and S. Zareba . "Studies on some mineral elements in coffee and coffee infusions. part II: Calcium, magnesium, nickel and chromium contents". Bromat. Chem. Toksykol. 33 ,241. 2000.

[26] R. Bulinski, Wyszogrodzka-Komal. and Z. Marzec. "Studies on some trace element content in polishmade food products. part XIX: lead, cadmium, chromium ,zinc, manganese, copper, nickel and iron content in some bee honey grades". Bromat. Chem. Toksykol. 28 (2), 151.1995.

[27] R. Bulinski and J. Błoniarz. "Studies on some trace elements in various grades of tea. Part II: lead, cadmium and nickel content in dry tea and tea infusions". Bromat.Chem .Toksykol. 31, 39. 1998.

[28] M. F. Hassan, M. M. Saleh and J. M. Salman. "A study of physicochemical parameters and nine heavy metals in the Euphrates river”, Iraq, E-J. of Chemistry 7, 685-692. 2010.

[29] Enviromental Health Criteria 108. Nickel.WHO, Genewa, 1991.

[30] D. Stojanovic and D. Nikic. "The exposure of the foetus and the breast feed newborn of women smokers to carcinogenic element nickel”. Medicine and bio. 12,89-92. 2005.

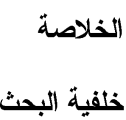

يعد حليب الانسان المصدر الوحيد كغذاء للرضع خلال اول اربعة او خمسة|تشهر من حياته. بعض المو اد الكيميائية قد تنتقل من خزنها في

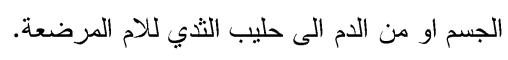

أهداف البحث

تحديد وقياس مستوى النيكل قي الحليب ألبشري للأمهات المرضعات ومعرفة علاقة الارتباط بين نركيز هذا العنصر بعض العوامل

المختلفة, إضافة لتحديد نسبة الأمهات ذات التركيز العالي من هذا العنصر الثقيل في الحليب عالي التركيز في هذا العنصر الثقيل أ.

طريقة العمل

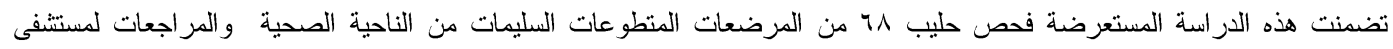

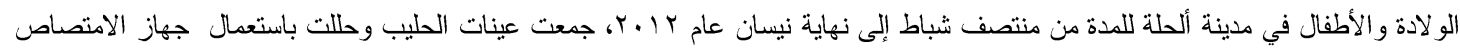

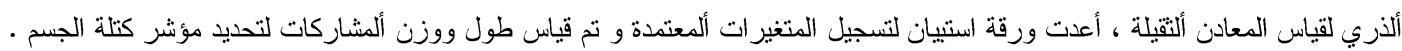

النتائج

أن متوسط تركيز النيكل كان (23.83 أخد 15.57)الحليب الأمهات المرضعات أعلى بشكل كبير من التركيز ألتي توصلت أليها دراسات عالمية

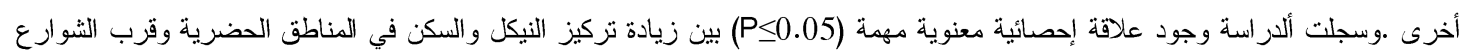

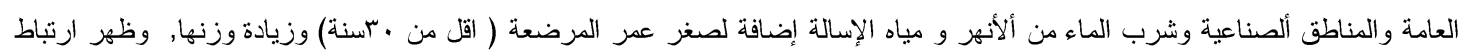

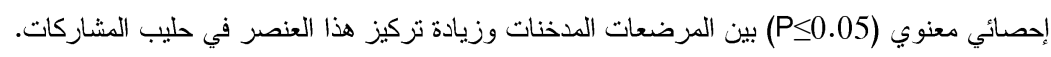

كان معدل المرضعات اللواتي لهن زيادة غير اعتيادية في تركيز النيكل،9\%٪، مما يؤشر وجود تلوث خطير بهذا المعدن في بيئة مدينة

نستتج من خلال دراستتا ان حليب الأمهات المرضعات ملوث بمعدن النيكل وهنالك حاجة ماسة لدراسات وطنية واسعة وجهود يجب أن

تبذل لرصد ألملوثات بيولوجيا و السيطرة على التلوث البيئي محليا.

الكلمات الدالة: تحيد تركيز النيكل، حليب الأمهات المرضعات في مدينة الحلة, بابل, العراق. 